\title{
STUDI PERUBAHAN PROFIL EKONOMI PENGHUNI TERKAIT LOKASI RUMAH SUSUN STUDI KASUS: BANDAR KEMAYORAN, KEBAGUSAN CITY DAN SENTRA TIMUR RESIDENCE
}

\author{
Freddy Kurniawan ${ }^{1}$, Nurahma Tresani ${ }^{2}$ dan Suryono Herlambang ${ }^{3}$ \\ ${ }^{1}$ Magister Teknik Perencanaan, Universitas Tarumanagara Jakarta \\ Surel: freddy.kurniawan@aol.com \\ ${ }^{2}$ Magister Teknik Perencanaan, Dosen Universitas Tarumanagara Jakarta \\ Surel: ntresani@gmail.com \\ ${ }^{3}$ Magister Teknik Perencanaan, Dosen Universitas Tarumanagara Jakarta \\ Surel: s.herlambang@gmail.com
}

\begin{abstract}
Flats as a vertical housing is one of many housing options in urban areas that are considered a strategy to overcome the problem of people's limited purchasing power for regular houses due to high land prices in urban areas. Various towers scattered around Jakarta and surrounding areas currently each have their own advantages or exclusive factors for residents such as the close proximity to the city center or workplace, close proximity to supporting facilities and the diversity of the environment around the towers become benchmarks in determining the location for their towers. Therefore, the occupancy of a flat, in this case the research samples taken are Bandar Kemayoran, Kebagusan City and Sentra Timur Residence, can be seen using the theory of location for housing selection and the impact of changes that occur in terms of economic profiles that change before and after living in the flats. The research method used is 2 sample test method to determine the condition of residents before and after moving to flats. The result of this study indicates that, if each location has its own role in the changes in economic profiles that occur, such as how significant the change is in terms of occupational fields and occupants' income, where each location shows different percentage in the change that occurs. The purpose of this study is to show the relationship between the resettlement of residents to flats and changes in economic profile (employment and income).
\end{abstract}

Keywords: flat, location of flats, changes in occupant economic profile.

\begin{abstract}
ABSTRAK
Rumah susun (rusun) sebagai perumahan vertikal adalah salah satu pilihan perumahan di daerah perkotaan yang dianggap strategi untuk mengatasi masalah keterbatasan kemampuan daya beli masyarakat untuk rumah tapak karena tingginya harga tanah di perkotaan. Berbagai rusun yang tersebar di Jakarta dan sekitarnya saat ini masing-masing memiliki daya tarik atau faktor-faktor tersendiri untuk para penghuni baik dari dekat dengan pusat kota atau tempat kerja, kedekatan dengan fasilitas pendukung dan keberagaman lingkungan sekitar rusun menjadi tolak ukur penghuni dalam menentukan lokasi rusun mereka. Sehingga terjadinya penghunian pada suatu rusun dalam hal ini sampel penelitian yang diambil adalah Bandar Kemayoran, Kebagusan City dan Sentra Timur Residence dapat dilihat dengan teori lokasi untuk pemilihan tempat tinggal serta dampak perubahan yang terjadi dari segi profil ekonomi yang berubah pada saat sebelum dan sesudah tinggal di rusun. Metode penelitian yang digunakan adalah metode 2 sampel tes untuk mengetahui keadaan penghuni sebelum dan sesudah pindah ke rumah susun. Hasil penelitian ini menunjukkan jika masing-masing lokasi memiliki peranan tersendiri dalam perubahan profil ekonomi penghuni yang terjadi, seperti seberapa besar perubahan dari segi bidang pekerjaan dan penghasilan penghuni yang setiap lokasi mempunyai perbedaan persentase perubahan yang terjadi. Tujuan dari penelitian ini adalah untuk menunjukkan adanya relasi antara perpindahan tempat tinggal penghuni menuju rumah susun terhadap perubahan profil ekonomi (bidang pekerjaan dan penghasilan).
\end{abstract}


Studi Kasus: Bandar Kemayoran, Kebagusan City,

Dan Sentra Timur Residence

Kata kunci: rumah susun, lokasi rumah susun, perubahan profil ekonomi penghuni.

\section{PENDAHULUAN}

\section{Latar Belakang}

Tingginya jumlah populasi penduduk suatu kota seringkali tidak sejalan dengan ketersediaan tempat tinggal yang memadai. Hal ini yang membuat harga tempat tinggal khususnya rumah tapak di pusat kota meningkat setiap tahunnya. Kemampuan daya beli masyarat yang tidak sebanding dengan peningkatan harga rumah tapak rupanya menjadi salah satu faktor masyarakat saat ini lebih memilih tinggal di rumah susun baik rumah susun sewa atau rumah susun milik. Selain itu berbagai faktor kedekatan dengan lokasi tempat kerja menjadi alasan orang - orang untuk tinggal di rumah susun. Fenomena ini menarik untuk dilihat dari segi profil ekonomi (yang di kategorikan dalam bidang pekerjaan, penghasilan dan pengeluaran) penghuni rumah susun terjadi perubahan atau tidak. Penelitian ini bertujuan untuk mengetahui bagaimana perubahan ekonomi yang terjadi pada penghuni rusunami terkait lokasi rusunami yang berbeda dan faktorfaktor pendorong terjadinya perubahan.

Penulis melalukan survei awal dan wawancara dengan penghuni rumah susun Greenpark View, Kalideres, terdapat beberapa fenomena terhadap penghuni yang tinggal dari berbagai alasan tinggal di rumah susun dan profil penghuni rumah susun yang beragam. Dalam penelitian ini peneliti memetakan rumah susun yang tersebar di Jakarta dan sekitarnya, sebanyak 26 rumah susun dikelompokkan berdasarkan jenis kegiatan disekitarnya dan faktor aksesibilitas (transport hub) yang dijadikan sebagai indikator penentuan sampel penelitian. Sehingga 3 lokasi sampel rumah susun yang terpilih adalah Bandar Kemayoran, Kebagusan City dan Sentra Timur Residence.

Berdasarkan teori tentang struktur perkotaan, terutama penelitian ekonomi lokasi, telah menempatkan trade-off antara biaya perjalanan dan pemilihan tempat tingal di theory of residental location (Alonso, 1964) dan (Muth, 1969). Dalam model monosentris lokasi perkotaan, rumah tangga mungkin lebih dekat untuk bekerja dan membayar lebih untuk perumahan, atau mungkin mencari jarak yang lebih jauh dari pekerjaan dan memiliki biaya perjalanan lebih besar dan perumahan yang lebih murah. Hal ini terutama berlaku di daerah yang cenderung memakai struktur perkotaan polisikentrik (polycentric urban structure). Pengembangan pendekatan life-course terhadap mobilitas dan migrasi membuat suatu hubungan yang bisa digunakan untuk meneliti perilaku penghuni dalam perubahan dalam ekonomi (pekerjaan, pendapatan dan pengeluaran).

Hubungan antara rumah dan tempat kerja merupakan komponen utama dari teori struktur ruang kota (urban spatial structure). Model ekonomi telah menekankan trade-off antara biaya perjalanan dan biaya perumahan dan menempatkan trade-off ini merupakan faktor dari pemilihan lokasi tempat tinggal. Perpindahan lokasi (migrasi) yang dilakukan oleh para individu masingmasing mempunyai alasan yang berbeda-beda. Beberapa alasan yang mendasari perpindahan tersebut karena faktor keluarga, gaya hidup, kesehatan dan perubahan iklim, dan tanpa disadari 
pilihan untuk berpindah tempat tinggal sejalan dengan keputusan untuk perubahan profil ekonomi individu.

Menurut Kuswartojo (2005), penyediaan perumahan bagi kelompok MBR bermula pada tahun 70-80an terutama di landed house. Pemerintah mulai mengembangkan rumah vertikal atau flats pada tahun 90-an, yang dimulai dengan pembangunan rumah susun Kebon Kacang di Jakarta Pusat, menggantikan permukiman kumuh di lokasi yang ada. Program ini kemudian diikuti oleh berbagai lokasi lain di Jakarta. Pembangunan perumahan vertikal atau rumah susun empat lantai pada waktu itu dianggap sebagai solusi yang menjanjikan untuk mengatasi masalah perumahan, terutama di kota-kota besar, kota metropolitan seperti Jakarta, di mana harga tanah sangat mahal. Meski pun kemudian perumahan vertikal memunculkan banyak rasa ketidakpuasan dari warga yang merasa tidak cocok tinggal di perumahan publik, tapi sekarang apartemen telah diterima dan dianggap sebagai bagian dari gaya kehidupan di kota besar.

Berdasarkan keterangan Mungkasa (2017) rumah susun diperuntukan untuk MBR dengan subsidi sebesar $80 \%$ yang dibebankan kepada APBD, program tersebut berlaku untuk rumah susun sederhana sewa (rusunawa) dan rumah susun sederhana milik (rumah susun).

Pembangunan rumah susun rata-rata dibangun oleh kerjasama developer, BUMN dan Pemda. Dari pihak developer sebagian dari kebijakan UUD tentang rumah susun komersial (apartemen) yang harus menyediakan kewajiban 20\% kompensasi rumah tinggal untuk MBR (yang dibagi menjadi rusunanawa dan rusunami). Hal senada tersebut juga diutarakan oleh Halim (2017). Namun konsep subsidi bagi rusunami hanya berlaku sekitar 6-7 tahun lalu dan keadaan saat ini sudah tidak ada subsidi karena saat ini rumah susun dihuni oleh kalangan menengah dan temuan di lapangan tidak ada batas pembelian unit menyebabkan penghapusan subsidi bagi rusunami dan rusunami berubah menjadi rumah tinggal komersil layaknya apartemen. Tetapi harga unit rusunami masih dalam kontrol oleh Pemprov DKI Jakarta dan terjangkau bagi sebagian masyarakat yang ingin mendapatkan tempat tinggal yang layak huni. Berangkat dari fenomena perpindahan masyarakat yang tinggal di rumah tapak ke rumah vertikal maka penelitian ini tentang adanya "Perubahan profil ekonomi terkait lokasi rumah susun" yang mengacu pada teori Chenery tentang perubahan profil ekonomi dikarenakan perubahan struktur ekonomi (spatial) yang terjadi dalam lingkungan sekitar. Sehingga mempunyai fenomena yang cukup menarik untuk diteliti, jika perpindahan tersebut memberikan dampak positif atau negatif bagi penghuni rumah susun.

\section{METODE PENELITIAN}

Metode penelitian yang digunakan adalah metode kuantitatif dan teknik analisa / penjelasan secara deskriptif, sedangkan metode kuantitatif digunakan untuk menjawab masalah perubahan pada aspek ekonomi dengan teknik analisis komparatif (paired $t$ test sample) yang membandingkan kondisi sebelum dan sesudah perpindahan penghuni ke rusun.

\section{Tabel 1. Sampel Penelitian}




\begin{tabular}{llcc}
\hline No & Rusun & Jumlah Lantai & Jumlah Sampel \\
\hline 1 & Sentra Timur Residence & 24 & 5560 \\
\hline 2 & Kebagusan City & 21 & 1747 \\
\hline 3 & Bandar Kemayoran & 20 & 418 \\
\hline & Total Unit & & 7725 \\
\hline
\end{tabular}

(Sumber: Hasil olahan peneliti, 2017)

Rumusan yang digunakan untuk menentukan jumlah sampel dalam penelitian ini adalah dengan menggunakan metode Slovin, yakni:

$$
n=\frac{N}{1+N(e)^{2}}
$$

Keterangan:

$n=$ ukuran sampel

$N=$ ukuran populasi

$e=\%$ ketidaktelitian karena kesalahan pengambilan sampel, misal $10 \%$

1. Sentra Timur Residence

$$
\begin{aligned}
\mathrm{n} 1 & =\frac{5560}{1+5560(0.10)^{2}} \\
\mathrm{n} 1 & =\frac{5560}{1+55.60}=96,52 \text { sampe] } \\
\mathrm{n} 1 & =96,52=100 \text { sampel }
\end{aligned}
$$

2. Kebagusan City

$$
\begin{aligned}
& \mathrm{n} 2=\frac{1747}{1+17.47}=94,58 \text { sampel } \\
& \mathrm{n} 2=94,58=100 \text { sampel }
\end{aligned}
$$

3. Bandar Kemayoran

$$
\begin{aligned}
& \mathrm{n} 3=\frac{418}{1+41.80}=97,66 \text { sampel } \\
& \mathrm{n} 3=97,66=100 \text { sampel }
\end{aligned}
$$

\section{Teknik Sampling}

Teknik sampling yang akan digunakan adalah teknik Proportional Sampling (sampel berimbang), yaitu teknik penentuan sampel dengan berdasarkan pertimbangan jumlah masingmasing kelompok subjek. Teknik ini digunakan cenderung terhadap populasi yang tidak homogen. Pada penelitian ini mengarahkan peneliti untuk mengambil anggota sampel secara proporsional pada setiap rusun.

- Rusun 1: 100 sampel

- Rusun 2: 100 sampel

- Rusun 3: 100 sampel

Langkah-langkah strategis yang akan dilakukan dalam penelitian ini adalah sebagai berikut:

- Melakukan mapping rusunami di Jakarta dan sekitarnya;

- Menentukan rusunami yang akan dijadikan objek penelitian; 
- Membuat transkrip kuesioner pedoman wawancara (sebagai acuan data yang dibutuhkan) antara lain:

- Faktor pemilihan lokasi rusunami (teori lokasi, Von Thunen);

- Faktor yang mempengaruhi perpindahan ke rusunami terkait (perpindahan lokasi, Yankow)

- Faktor yang mempengaruhi perubahan profil ekonomi (faktor yang berperan, Yankow)

- Menjalin hubungan baik dengan narasumber dan penghuni rusunami;

- Mendeskripsikan hasil wawancara sebagai tambahan penelitian;

- Memuat segala temuan dan observasi kedalam laporan penelitian.

\section{Objek Penelitian}

- Berupa kondisi lapangan: meliputi lokasi, keadaan rusunami dan lingkungan sekitar.

- Para penghuni rusunami: end user atau penyewa, lama tinggal dan profil.

\section{HASIL PENELITIAN DAN PEMBAHASAN}

\section{Analisis}

Menurut Hollis Chenery (1975), perubahan profil ekonomi dikarenakan perubahan struktur ekonomi (spatial) yang terjadi dalam lingkungan sekitar. Perubahan profil ekonomi yang dimaksud adalah bidang kerja, pekerjaan, penghasilan dan pengeluaran yang dikaitkan dengan lingkungan sekitar yakni lokasi. Kanchier (1987) menyimpulkan faktor penentu perubahan profil ekonomi menjadi 5 bagian diantaranya: kondisi ekonomi, hiburan, lingkungan kerja, tanggungan keluarga dan kebutuhan hidup. Maka indikator yang digunakan perubahan profil ekonomi pada penelitian ini adalah:

- Bidang Pekerjaan

- Pengeluaran

- Penghasilan

Tabel 2. Hubungan Lokasi dan Teori Perubahan Profil Ekonomi Penghuni

\begin{tabular}{llcl}
\hline No & Indikator & Kriteria Pada Teori & Status \\
\hline 1 & Bidang Pekerjaan & $\checkmark$ & Sesuai \\
\hline 2 & Pengeluaran & $\checkmark$ & Sesuai \\
\hline 3 & Penghasilan & $\checkmark$ & Sesuai \\
\hline
\end{tabular}

(sumber: olahan peneliti, 2017)

Analisis:

- Bidang Pekerjaan

Berdasarkan kondisi eksisting, sebagian besar penghuni ketiga rusunami masih mempertahankan bidang pekerjaannya (sebelum pindah ke rusunami) dari hasil data temuan lapangan kuesioner dan analisis yang telah dilakukan menunjukkan rata-rata persentase penghuni yang masih mempertahankan pekerjaannya baik sebelum dan sesudah pindah ke rusunami sebesar $74 \%$ maka selisih sebesar $26 \%$ adalah rata-rata penghuni dari ketiga rusunami yang berubah bidang pekerjaannya. Dengan demikian, hal ini menunjukkan tidak terlalu berpengaruh antara lokasi dan perubahan di bidang pekerjaan sesuai dengan teori perubahan profil ekonomi.

- Pengeluaran 
Berdasarkan analisis menggunakan $t$ two paired sample test pada tahap sebelumnya terlihat jika dari sampel penghuni ketiga rusunami sebagian besar mengalami perubahan pada variabel pengeluaran makan, air listrik, pendidikan, kredit barang dan kebutuhan lainnya. Dengan demikian, hal ini menunjukkan adanya relevansi (kesesuaian/ saling berhubungan) antara lokasi dan perubahan di pengeluaran sesuai dengan teori perubahan profil ekonomi.

- Penghasilan

Berdasarkan hasil analisis perubahan pengeluaran penghuni maka secara langsung berdampak pada pendapatan penghuni yang meningkat sejalan dengan jumlah pengeluaran yang telah dilakukan. Maka sesuai dengan teori Becker yang menyatakan bahwa peningkatan pendapatan secara tidak langsung mempengaruhi pola konsumsi (pengeluaran) individu, sehingga hal ini menunjukkan adanya relevansi (kesesuaian/ saling berhubungan) antara lokasi dan perubahan profil ekonomi penghuni sesuai dengan teori yang digunakan. 
Tabel 3. Rekap Crosstabulation Usia*Pekerjaan dan Usia*Penghasilan

\begin{tabular}{|c|c|c|c|c|c|c|c|c|c|}
\hline \multirow{2}{*}{ No } & \multirow{2}{*}{$\begin{array}{l}\text { Rumah } \\
\text { Susun }\end{array}$} & \multirow{2}{*}{ Penghuni } & \multirow{2}{*}{ Usia (tahun) } & \multicolumn{2}{|l|}{ Sebelum Pindah } & \multicolumn{2}{|l|}{ Sesudah Pindah } & \multicolumn{2}{|c|}{ Keterangan } \\
\hline & & & & Pekerjaan & Penghasilan & Pekerjaan & Penghasilan & Pekerjaan & Penghasilan \\
\hline 1 & \multirow{2}{*}{$\begin{array}{l}\text { Bandar } \\
\text { Kemayoran }\end{array}$} & Milik & $20-40(80 \%)$ & $\begin{array}{l}\text { Karyawan } \\
\text { Swasta }(68.8 \%)\end{array}$ & $\begin{array}{l}3.5-6.9 \text { Juta } \\
(54.7 \%)\end{array}$ & $\begin{array}{l}\text { Karyawan Swasta } \\
(68.8 \%)\end{array}$ & $\begin{array}{l}3.5-6.9 \text { Juta } \\
(45.3 \%)\end{array}$ & - & $\uparrow$ \\
\hline 2 & & Sewa & $20-40(72.7 \%)$ & $\begin{array}{l}\text { Karyawan } \\
\text { Swasta }(68.4 \%)\end{array}$ & $\begin{array}{l}<3.5 \text { Juta } \\
(44.7 \%)\end{array}$ & $\begin{array}{l}\text { Karyawan Swasta } \\
(65.8 \%)\end{array}$ & $\begin{array}{l}3.5-6.9 \text { Juta } \\
(44.7 \%)\end{array}$ & $\checkmark$ & $\uparrow$ \\
\hline 3 & \multirow{2}{*}{$\begin{array}{l}\text { Kebagusan } \\
\text { City }\end{array}$} & Milik & $20-40(70.4 \%)$ & $\begin{array}{l}\text { Karyawan } \\
\text { Swasta }(64.7 \%)\end{array}$ & $\begin{array}{l}<3.5 \text { Juta } \\
(33.3 \%)\end{array}$ & $\begin{array}{l}\text { Karyawan Swasta } \\
(54.9 \%)\end{array}$ & $\begin{array}{l}3.5-6.9 \text { Juta } \\
(33.3 \%)\end{array}$ & $\checkmark$ & $\uparrow$ \\
\hline 4 & & Sewa & $20-40(56.1 \%)$ & $\begin{array}{l}\text { Karyawan } \\
\text { Swasta }(55.7 \%)\end{array}$ & $\begin{array}{l}<3.5 \text { Juta } \\
(44.3 \%)\end{array}$ & $\begin{array}{l}\text { Karyawan Swasta } \\
(63.9 \%)\end{array}$ & $\begin{array}{ll}3.5-6.9 & \text { Juta } \\
(41 \%) & \\
\end{array}$ & $\checkmark$ & $\uparrow$ \\
\hline 5 & \multirow{2}{*}{$\begin{array}{l}\text { Sentra } \\
\text { Timur } \\
\text { Residence }\end{array}$} & Milik & $20-40(65.6 \%)$ & $\begin{array}{l}\text { Karyawan } \\
\text { Swasta }(67.8 \%)\end{array}$ & $\begin{array}{l}3.5-6.9 \text { Juta } \\
(42.4 \%)\end{array}$ & $\begin{array}{l}\text { Karyawan Swasta } \\
(59.3 \%)\end{array}$ & $\begin{array}{l}7-9.9 \text { Juta } \\
(35.6 \%)\end{array}$ & $\checkmark$ & $\uparrow$ \\
\hline 6 & & Sewa & $20-40(51.3 \%)$ & $\begin{array}{l}\text { Karyawan } \\
\text { Swasta }(43.4 \%)\end{array}$ & $\begin{array}{l}3.5-6.9 \text { Juta } \\
(43.4 \%)\end{array}$ & $\begin{array}{l}\text { Karyawan Swasta } \\
(50.9 \%)\end{array}$ & $\begin{array}{l}3.5-6.9 \text { Juta } \\
(34 \%)\end{array}$ & $\checkmark$ & $\uparrow$ \\
\hline
\end{tabular}

No

\section{Kesimpulan}

1 tidak ada perubahan pada pekerjaan, namun terdapat perubahan yang tidak terlalu signifikan pada bagian penghasilan

2 ada perubahan pada pekerjaan tapi tidak terlalu signifikan, terdapat perubahan yang signifikan pada bagian penghasilan

3 ada perubahan tapi tidak terlalu signifikan, terdapat perubahan yang signifikan pada bagian penghasilan

4 ada perubahan pada pekerjaan pada pekerjaan tapi tidak terlalu signifikan, terdapat perubahan yang signifikan pada bagian penghasilan

5 ada perubahan pada pekerjaan tapi tidak terlalu signifikan. terdapat perubahan yang signifikan pada bagian penghasilan

6 ada perubahan pada pekerjaan tapi tidak terlalu signifikan, terdapat perubahan yang tidak terlalu signifikan pada bagian penghasilan 


\section{Penentuan Lokasi Rumah Susun}

Faktor-faktor yang menjadi pertimbangan penghuni dalam menentukan lokasi masing-masing rumah susun terdapat preferensi yang berbeda-beda berikut kesimpulannya:

- Bandar Kemayoran

Faktor aksesibilitas dan kedekatan terhadap fasilitas transport hub, sekolah, pasar dan rumah sakit lebih penting bagi penghuni Bandar Kemayoran, namun keberagaman lingkungan sekitar tidak penting bagi penghuni Bandar Kemayoran.

\section{- Kebagusan City}

Faktor aksesibilitas dan kedekatan terhadap fasilitas transport hub, sekolah, pasar, rumah sakit dan keberagaman lingkungan sekitar merupakan faktor yang penting bagi penghuni Kebagusan City.

\section{- Sentra Timur Residence}

Faktor aksesibilitas dan kedekatan terhadap fasilitas transport hub, sekolah, pasar, rumah sakit dan rekreasi lebih penting bagi penghuni Sentra Timur Residence, namun keberagaman lingkungan sekitar tidak penting.

Sehingga faktor yang paling penting bagi sebagian besar penghuni rumah susun adalah faktor aksesibilitas dan kedekatan terhadap fasilitas sekitar.

\section{Perubahan Profil Ekonomi Penghuni}

Perubahan profil ekonomi penghuni pada bidang pekerjaan berdasarkan tiga rumah susun yang diteliliti tidak terlalu signifikan. Sebagian besar penghuni masih mempertahankan pekerjaan lamanya baik sebelum dan sesudah pindah ke rumah susun. Adapun perubahan bidang pekerjaan yang terjadi pada masing-masing penghuni dan lokasi penelitian adalah sebagai berikut:

- Penghuni Bandar Kemayoran $\quad: 21 \%$

- Penghuni Kebagusan City $\quad: 28 \%$

- Penghuni Sentra Timur Residence : :29\%

Perubahan profil ekonomi dari segi bidang pekerjaan sesudah pindah ke rumah susun tidak terlalu besar atau signifikan, yang terbesar sedangkan terjadi pada Sentra Timur Residence dengan 29\%. Perubahan profil ekonomi penghuni dari segi penghasilan sesudah pindah ke rumah susun dapat tercermin dari perubahan pengeluaran penghuni yang bertambah/ meningkat saat sebelum dan sesudah pindah ke rumah susun. Maka dapat disimpulkan bahwa perubahan pengeluaran penghuni yang cenderung meningkat berdampak pula terhadap meningkatnya jumlah pendapatan penghuni di tiap rumah susun.

\section{Kaitan Lokasi Terhadap Perubahan Profil Ekonomi Penghuni}

Berdasarkan penelitian yang dilakukan pada tahap akhir peneliti mencoba untuk mengkaitkan antara hubungan perubahan profil penghuni ekonomi terkait lokasi. Sebelumnya sudah dijabarkan, jika lokasi memiliki peranan penting dalam penentuan tempat tinggal bagi penghuni, seperti: aksesibilitas dan kedekatan dengan fasilitas sekitar. Kedua faktor tersebut yang menjadi latar belakang terpilihnya suatu lokasi tempat tinggal yang memenuhi kriteria sebagai lokasi yang layak dihuni oleh para penghuni. Tentunya fenomena transformasi dan perpindahan penghuni yang sebelumnya tinggal di rumah tapak menuju rumah vertikal secara tidak langsung 
juga memberikan dampak pada perubahan pola hidup penghuni dalam penelitian ini lebih di fokuskan pada perubahan profil ekonomi penghuni yaitu bidang pekerjaan dan penghasilan. Yang sebagian besar perubahan profil ekomoni cukup signifikan terjadi pada segi penghasilan, bidang pekerjaan cenderung tidak mengalami perubahan yang signifikan. Pada table 3.2 telah di analisis faktor-faktor apa saja yang menyebabkan perubahan profil ekonomi tersebut. Berikut adalah kesimpulan keselurahan dari penelitian ini:

- Bandar Kemayoran

- Faktor aksesibilitas (jarak ke tempat kerja) dan kedekatan dengan fasilitas (sekolah, pasar dan rumah sakit).

- Perubahan profil ekonomi yang terjadi dari segi bidang pekerjaan tidak ada perubahan, dari segi penghasilan terjadi perubahan cenderung meningkat (dari $<3.5$ juta menjadi 3.5-6.9 juta).

- Kebagusan City

- Faktor aksesibilitas (jarak ke tempat kerja dan ke pusat kegiatan) dan kedekatan dengan fasilitas (transport hub, sekolah, pasar dan rumah sakit) dan keberagaman lingkungan sekitar.

- Perubahan profil ekonomi yang terjadi dari segi bidang pekerjaan ada perubahan namun tidak terlalu signifikan, dari segi penghasilan terjadi perubahan meningkat yang cukup tinggi (dari < 3.5juta menjadi 3.5-6.9 juta).

- Sentra Timur Residence

- Faktor aksesibilitas (jarak ke tempat kerja dan ke pusat kegiatan) dan kedekatan dengan fasilitas (transport hub, sekolah, pasar dan rumah sakit).

- Perubahan profil ekonomi yang terjadi dari segi bidang pekerjaan tidak ada perubahan, dari segi penghasilan terjadi perubahan meningkat cukup tinggi (dari 3.5-6.9 juta menjadi 7-9.9 juta).

Dari hasil analisis diatas dapat disimpulkan bahwa fenomena perpindahan penghuni ke rumah susun memberikan dampak yang positif bagi kehidupan penghuni rumah susun. Hal ini terlihat dari jumlah penghasilan yang meningkat tanpa banyak perubahan pada bidang pekerjaannya, dalam penelitian ini adalah para penghuni Sentra Timur Residence yang memiliki persentase perubahan profil ekonomi yaitu bidang pekerjaan (29\%) dan penghasilan (3.5-6.9 juta menjadi 79.9). Terutama dilihat dari lokasi Sentra Timur Residence yang masuk dalam kegiatan industri. Maka dapat diartikan jika lokasi suatu rumah susun dapat memberikan dampak pada perubahan profil ekonomi penghuni. 


\section{KESIMPULAN DAN SARAN \\ Kesimpulan \\ Profil Penghuni:}

- Kelompok penghuni usia yang mendominasi di ketiga rusunami adalah usia 20-40 tahun. Bandar Kemayoran (61\%), Kebagusan City (68\%) dan Sentra Timur Residence (71\%).

- Kelompok penghuni beli / milik terbanyak berada di Bandar Kemayoran (62.7\%) dan Sentra Timur Residence (53\%), sedangkan penghuni sewa / kontrak berada di Kebagusan City (54\%).

- Pekerjaan paling dominan adalah karyawan swasta.

Lokasi Rusunami:

- Bandar Kemayoran mempunyai aksesibilitas dan keberagaman lingkungan sekitar yang baik. Namun kedekatan dari segi transport hub kurang baik.

- Kebagusan City mempunyai aksesibilitas, kedekatan dengan fasilitas dan keberagaman lingkungan yang baik.

- Sentra Timur Residence mempunyai aksesibilitas, kedekatan dengan fasilitas dan keberagaman lingkungan yang baik.

Perubahan Profil Ekonomi Penghuni:

- Sebagian besar penghuni baik penghuni milik atau sewa mengalami perubahan profil ekonomi dalam penghasilan per bulannya yang mengalami peningkatan. Namun tidak disertai dengan perubahan bidang pekerjaan.

\section{Saran}

\section{Peran Pemerintah}

- Melanjutkan kebijakan pembangunan 1000 tower rumah susun untuk kebutuhan tempat tinggal bagi masyarakat.

- Menyiapkan infrastruktur pendukung seperti akomodasi transportasi umum yang terhubung dengan rumah susun.

\section{Peran Pengelola dan Pengembang}

- Mewujudkan lingkungan rumah susun yang aman, nyaman dan bersih.

- Memberikan fasilitas pendukung seperti sekolah, klinik dan pasar bersih di dalam area rumah susun.

\section{Peran Penghuni Rumah susun}

- Membantu penghuni dalam menentukan lokasi rumah susun.

- Meningkatkan kesadaran penghuni untuk turut serta menjaga dan merawat lingkungan rumah susun.

\section{Penelitian Lanjutan}

- Pengaruh keberadaan rumah susun (Bandar Kemayoran, Kebagusan City dan Sentra Timur Residence) terhadap hunian/ fungsi-fungsi lainnya di sekitar rumah susun.

- Evaluasi property management dalam pengelolaan tiap rumah susun dengan konsep ramah lingkungan sesuai dengan standar yang berlaku. 


\section{Ucapan Terima Kasih}

Peneliti tidak dapat menyelesaikan tesis ini tanpa adanya bantuan dari berbagai pihak, baik secara langsung mau pun tidak langsung, karena itu dalam kesempatan ini peneliti hendak mengucapkan terima kasih yang mendalam atas segala bentuk bantuan yang diberikan, yaitu kepada:

1. Keluarga tercinta Ayah, Ibu dan Adik atas doa dan dukungannya;

2. Ibu Dr. Ir. Nurahma Tresani, MPM., selaku dosen pembimbing 1;

3. Bapak Suryono Herlambang, ST., MSc., selaku dosen pembimbing 2;

4. Para dosen Magister Teknik Perencanaan Universitas Tarumanagara;

5. Teman Angkatan 24 Magister Teknik Perencanaan Universitas Tarumanagara atas motivasi dan masukan yang diberikan;

6. Seluruh narasumber yang terlibat, penghuni serta pengelola rusun Bandar Kemayoran, Kebagusan City dan Sentra Timur Residence;

7. Teman terdekat, Franky Adiredja dan kekasih tercinta, Veldira Thalia yang senantiasa memberikan motivasi dan semangat.

\section{REFERENSI}

Alonso, William. 1964. Location and Landuse. Cambridge, MA: Harvard University Press.

Becker, G. 1965. A Theory of the Allocation of Time: The Economic Journal LXXV (299): 493-517. September

Clark and Withers. 1999. Changing Jobs and Changing Houses: Mobility Outcomes of Employment Transitions. Journal of Regional Science.

Chenery. Hollis Burnley. 1989. Pattern of Development. World Bank.

Evans, Alan W. 1985 Trade Off Theory.

Hall, Jon, and Mike Berry. 2007. Public Housing: Shifting Client Profiles and Public Housing Revenues. Australian Housing and Urban Research Institute. Melbourne Victoria.

Hughes and James. 1975. Transportation Implications: Changing Spatial Distributions of Job and Residences

Markey, J and Parks II, W. 1989. Occupational change: pursuing a different kind of work. Monthly Labor Review, 54(3): 93-610.

Muth, Richard. 1969. Migration Dynamics: A Life Course Approach. Amsterdam: Thesis Publishers.

Ni Wayan Suriastini. 2006. Hubungan Umur dengan Perubahan Pekerjaan: Suatu Aplikasi Metaanalisis dalam Ukuran Sampel. Populasi, 17(1). ISSN: 0853-0262

Rabinowitz, H.Z. 1988. Real Estate Planning. New York: McGraw Hill Inc.

Sjaastad, Larry. 1962. The Cost and Returns of Human Migration. Journal of Political Economy, 70, 80-93.

Tarigan, Robinson. 2005. Von Thunen Location Theory: Balancing Land-Use Allocation with Transportation Cost. Center for Spatially Integrated Social Science.

Tjuk, Kuswartojo, Perumahan dan pemukiman di Indonesia (Bandung: Institut Teknologi Bandung, 2005).

Turner, John. 1976 Housing by People: Towards Autonomy in Building Environments. London: Marion Boyars Publishers Ltd.

Yankow, J. 2003. Migration, job change and wage growth: a new perspective on the pecuniary return to geographic mobility. Journal of Regional Science, 43(3): 483516. 